\title{
Linguosemiotic Types of Conceptualizations in Language and Culture
}

\author{
Sergei G. Proskurin and Anna V.Proskurina* \\ Novosibirsk State Technical University \\ 20 K. Marx, Novosibirsk, 630073, Russia
}

Received 06.01.2018, received in revised form 24.01.2018, accepted 05.02.2018

The current article deals with some linguosemiotic types of conceptualizations in language and culture. The questions are referred to the identification of conceptual models in semiotics of Indo-European Culture. We understand under the concept of linguosemiotic types conceptual systems, which include all the synchronous domain of senses as well as prehistory (i.e. evolution). Thus we focus upon conceptual systems of Indo-European language and culture, namely research systems, which study prewritten and written traditions and conceptual structures (concepts, mythopoeic archetypes etc.) of hypothetical and historic importance. The subject of research is a key cultural concept, cultural frames, and grammatical layers and domains.

Keywords: Indo-European semiotics, conceptualizations, conceptual models, cultural frames, grammatical concepts.

The research was funded by grant № 14-28-00130 of the Russian Science Foundation. The project is carried out at the Institute of Linguistics, Russian Academy of Sciences.

DOI: 10.17516/1997-1370-0238.

Research area: philology, culturology.

Semiotics, as a science developing questions of the functioning of sign systems, explores the main function of sign systems - ways of transferring and storing non-genetic information in language and culture. Thus, issues related to the identification of conceptual models of the Indo-European language and culture are related to the problems of a new applied discipline - the semiotics of Indo-European culture. The fundamental difference between the new discipline and traditional studies within the general semiotics of culture (see: Stepanov,
1971) is its orientation towards the conceptual systems of the Indo-European language and culture, namely, to research systems studying the interaction of language and culture on the basis of pre-written and written traditions of the IndoEuropean area, as well as conceptual structures (concepts, mythological archetypes, etc.) that have both a hypothetical and historical interpretation. By "liguosemiotic types" in this paper we mean such conceptual systems that include the entire synchronous domain of meanings, including the prehistory (i.e., evolution).

(C) Siberian Federal University. All rights reserved

* Corresponding author E-mail address: s.proskurin@mail.ru, a.vyacheslavovna@gmail.com 
Evolution of meanings is directly connected with cultural transfer, i.e. transfer of information in time and space. So, the (lingua) cultural transfer is represented by us as a transfer of information in time, which is considered in two ways: the momentary transfer of information is communication, whereas the transfer of information under conditions of different generations is a transmission. "Communication" and "transmission" are studied within the framework of the mediology, the scientific discipline proposed by Régis Debray (Debray, 2010) considering means that allow information to be transferred in time and space. Any language is a means of communication, allowing interlocutors to come to an understanding, in addition, it is endowed with the function of transmitting information in generations. The function of transmission, being a function of language and cognitive system, perpetuates "some basic identity" common to all those people who use their native language, and allows descendants to feel belonging to their ancestors, while accumulating the collective memory of a particular historical group. The notion of "communication" refers to the transfer of information in space within the same spatio-temporal sphere, and to the term "transmission" - everything that relates to the dynamics of collective memory (the transfer of information in space and time).

Communication, according to Régis Debray, is a transfer of information in space within the same spatio-temporal sphere, that is, the translation of messages into a given moment of the present time. If we describe communication from the point of view of the time scale, it is synchrony (simultaneity of the "question" and "answer"), relevance (the addressee addressing the addressee, building his message based on actual events) and speed (determined by the fact that the addressee and addressee are in the same spatio-temporal sphere, in the modern era). Transmission is the transfer of information between different spatio-temporal spheres. In other words, the transmission is a message related to the dynamics of the collective memory. The transmission is diachrony, imprint (with the help of a material carrier, a connection is made between the addressee and the addressee) and eternity (thanks to the connections through the generation, a historical transmission horizon directed at the accumulation invariant is possible for all epochs). Since there is no perpetuation without materialization, for the purposes of transmission, the best approach is not linguistic accompaniment, but a cognitive scenario based on a cumulative function. The term "transfer" implies the transfer of information from generation to generation, and while the cycle of transmission is realized, our values and our culture live. People, according to Régis Debray, deliberately convey and perpetuate just "the most valuable for them", while projecting themselves into the common future (see: Debray, 2010: 15, $29,50)$.

\section{The key cultural concept and its role in the reconstruction of Indo-European culture}

"The originality of the ideology of the family, characteristic of the Slavs, looks like an archaism in the Indo-European retrospective, highly productive in the cultural and cognitive terms (the problem of the etymological identity of the i.e. *gno- "to give birth, to be born" *gno-2 "to know a person"). The originality of the ideology of the clan among the Slavs is vividly reflected in the aforementioned key word of the Slavic culture ${ }^{*}$ svoj and in the collective archival individuality characteristic of the latter archaic. Further study of the root $*_{\text {svoj (i.e. - }}$ $*_{\text {su) }}$ is fruitful for the possibility of exploring ancient ideology from within: Slav. * ${ }^{*}$ s-mrtb 
"death" itself "its own plausible death" as an Indo-European archaism" (Trubachev, 1987: 6061). So it is known that the formant *su and the morpheme ${ }^{*} \mathrm{r}$ interact in the topic of kinship: Old English sweor, sweger, Russian свекор, свекровь (Old Indian svadhina "freedom", Russian свобода). The key word of the Indo-European culture *sụe "its own" forms a layer of lexemes subordinate to a strict hierarchy: the names of kinship (*-r) listed above without brackets refer to Indo-Europeans as people, members of a society close to the genus, considered to be theirs and entitled to freedom, those the right to live in the territory of society (Polomé, 1982). As most Indo-Europeanists believe, the word *sue is included in the reconstruction scheme of the "anthropocentric" model of the world, viewed in a horizontal projection and corresponding, in their opinion, the concept of originality of the genus and clan ideology (Trier, 1942; Abaev, 1970; Polomé, 1982, 1985, 1989; Kolesov, 1986; Trubachev, 1987). A key aspect of the "anthropocentric" model is the emphasis "on the contrast" inner-external, which prevails at every level of social structure and human relations. writes E. Polome. - Inside his family, clan, tribe, the Indo-European is safe, when outside he is in danger. Inside his family, clan, tribe, he has all the necessary rights and privileges that rely on free members of society, as evidenced by the first element of the Slavic "freedom" and Old Indian svadhina - "free" (Polomé, 1982: 156) (compare also with Old Germanic, *frija - *frijond - "free", “friend", Hettite ara: arawa - "too" (Puhvel, 1984: 116-121). In the Anglo-Saxon tradition, the idea of separation of its internal and hostile external is embodied in the motivation of the typologically similar name frithgeard, which served to denote "the place where calm and peace are affirmed". All space appears conditionally divided into two spheres, and the inner frith is "peaceful" (from Old English freo - "free", Old Indian. priyate - "loves", Indo-European *pri "to love") (Holthausen, 1974). This image is the type of relations that is "own" in the fence and the "alien" outside. It is the basis of reconstruction in the horizontal section, and the association of space within the fence with the territory of the free space, opposed to the external hostile, belongs to the core of the Indo-European conceptions, reflected in most historical traditions.

Thanks to the scrutiny of the root *svojb (Indo-European $-{ }^{*}$ su), studies of the ancient ideology of the word death became possible: "Slav. *s-mbrtb death itself is a plausible death as an Indo-European archaism" (Trubachev, 1987: 60-61). The own death is a natural death. There is controversy among etymologists about the prefix *su in this word. It remains controversial: Does the prefix *su- in this word mean "own" or "good", i.e, is the own death also the good death? In any case, the natural death remains an invariant of the expressions. The direct designation of "natural" in essence coincides with the euphemisms "own", "good" (Stepanov, 2003: 9). The Greek term "euphemism" has two opposite meanings: 1) "to pronounce words that bear a good omen"; 2) "Avoid words that promise bad things", whence and "keep silent" (Benveniste, 2002). "The term "euphemism" comes from the Greek word euphemismos (eu"good" and phemi - "say") - "I speak politely" (Arapova, 1990: 590). Euphemism is the replacement of an undesirable expression and/ or a word with a neutral or positively connotated designation in order to prevent conflict in communication and/or to avoid unpleasant phenomena of reality (Baskova, 2009: 16). According to Yu.S.Baskova, originally ethnographers studied the euphemisms (they studied the meaning of taboo words in primitive communities (D.K.Zelenin, A. Meillet)), because in the linguistic plan, euphemisms are closely related to the phenomenon of taboo. 
"Euphemisms are replaced, permitted words that are used instead of forbidden (tabooed) words" (Reformatsky, 1996: 105).

The word "forðferde" is a euphemism; one of its possible semantics is to "go forward". In turn, ford is associated with the place of sunrise, the east. Thus, it is noted that there is an etymological and further typological relationship between $3 a-$ падь and за-дъ, съверъ and шюи, въс-токъ and nepe- $\partial b$ (compare the same semantic close roots, reinforcing each other, in one word: sыс-npb, пре-выс-ить, вос-пре-пятствовать, пре-взоümu).

It is remarkable that the Old English word "east" (east, from the east) is treated in two ways: 1) the rising sun, illuminating everything around, "light from the east"; 2) lēoht ēastan - "light from the east" - God's help. The second interpretation of this word, naturally, is connected with the Christian view of the East: in this case it acts as a sacred part of the world (Christian temples and burials are oriented to the east) (see: Karpova, 2002). "The place of evil, gloomy and hostile to people happens in the Edda's myths, either the eastern or the northern outskirts" (SteblinKamensky, 1978: 40).

Let us turn to the etymological dictionary of the Old English language, consider the internal form of the word "forðferan" ("die"), "forðfrednes" ("death"): 1. "faran" - a strong verb: "go", "move", "go", "leave", "act”, “endure"; "gefaran" means "dying", "advancing", "taking over", "catching", "keeping"; English. "fare”; Old Frisian, Old Icelandic "fara"; Old Saxon, Old High

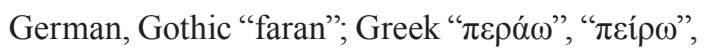

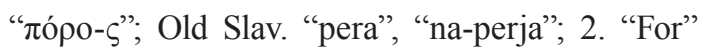
is a preposition: before, on the side, instead of, owing, in spite of; adverb "fer": English "for", Old Frisian "for-", "ur-", "far-", "fir-", Old Icelandic "for-", Gothic "faúr", Latin "por-", Greek " $\pi \alpha ́ \rho$ $(\alpha)$ "; 3. "Ford" - an adverb: "further", "forward", "from here", "from there", "constantly", "still", "simultaneously"; preposition: "in time", English "Forth", Old Frisian, Old Saxon "cort" (Holthausen, 1974: 98, 112).

Interestingly, in the Anglo-Saxon Chronicle (The Anglo-Saxon Chronicle), the earliest records of death are associated with the euphemism of the concept of "death", while later ones show a direct nomination. By the end of the Anglo-Saxon Chronicles in the records after 1137 year ("Manuscript E"), the lexeme "forðferde" ("died") ceases to occur. It is replaced by lexemes: 1137 - "steorfan" ("to die", "to die of hunger/cold"), 1154 - "dēadian" ("to die"). However, the text from 1140 contains a new lexeme "dēadian" ("to die") along with the previous one - "forðferde" ("died"). Here are the contexts that tell of the Civil War in England (1135-1154): 1137 - "Đis gære < ..> Pa was corn dære. 7 flec 7 cæse 7 butere. for nan ne wæs o pe land. Wreccemen sturuen of hungæ $r<\ldots$, ("This year $<\ldots>$ Then was corn dear, and flesh, and cheese, and butter, for there was none in the land. Wretched men died of hunger $<\ldots>$ ".); 1140 - "On pis gær $<\ldots>$ perefter fordfeorde Willelm ærcebiscop of Cantwarberi. 7 te king makede Teodbald ærcebiscop pe was abbot in the $\mathrm{Bec}<\ldots>7$ wærd ded 7 his moder beien. 7 te eorl of Angæu wærd ded. 7 his sune Henri toc to pe rice" ("In this year $<\ldots>$ After this William, archbishop of Canterbury, died, and the king made Theobald archbishop, who had been abbat at Bec. $<\ldots>$ And the earl of Anjou died; and his son Henry took the kingdom"); 1154 - "On pis gær wærd pe king Stephne ded 7 bebyried per. his wif 7 his sune wæron bebyried æt Fauresfeld $<\ldots>$ abbod of Burch $<\ldots>$ pa sæclede he 7 ward ded iiii Nonæ Ianuarii $<\ldots$.. " ("In this year died the king Stephen, and he was buried where his son and his daughter were buried, at Favresfeld; they had made that minster $<\ldots>$ abbot of Peterborough $<\ldots>$ he sickened, and died on the $4^{\text {th }}$ of the nones of January $<\ldots>$ ". $)$. 
Note that euphemisms themselves are secondary, but sometimes they serve as a basis for word formation, as in the morpheme *su (cyмерть), which is a part of the Russian word "death", i.e., it's the own good death. Paradoxically, a euphemism can be the basis for the nomination of a neutral term. This is evidenced by the history of the Anglo-Saxon Chronicles. The later lexemes "steorfan" (to die of hunger/cold) and "dēadian" (to die) replace the "forðferan" (to die). It is noteworthy that then the Scandinavian borrowed word "deyja" (to die), the modern lexeme "to die", will become a part of English vocabulary, ousting the Old English words.

\section{Conceptual cultural frames}

It is believed that in different representatives of related traditions we are talking about the same denotata (as if "things"), which correspond to the same concepts or develop the same archetype.

The most common approach at the present time in the reconstruction of cultural phenomena on a linguistic basis (Indo-European languages), for example, myths, is based on the concept of monogenesis: the mythological material of different societies is traced back to the common initial state, which associates language, society and culture on different foundations. Such inductive historical and prehistoric reconstruction of prototypes (or archetypes) always carries additional benefits, since independent elements from different languages and cultures acquire individual significance, after an inductive hypothesis has already been proved. Such an approach, in order to be fruitful, needs a wide and deep coverage of the material in several dimensions and sufficient similarity and difference, allowing both positive conclusions and control over the screening material. Thanks to this approach, the names of objects of material culture, flora and fauna, metals, etc. are easily established in this field.
Comparison of the words of historical IndoEuropean languages that formally correspond to each other allows us to reconstruct the source lexical archetypes distributed with dialects with definite denotative ("real") semantics, which are established according to concrete meanings by historically attested forms of words in different languages.

The attempt to define conceptualized areas in a language depends on the definition of integral and differential signs of the word, as well as on the point of view chosen by a researcher. Sometimes the researcher chooses in the form of a conceptual system a list of words, carriers of general meanings, and in a more general linguocultural sense, possessing common conceptual cultural frames. Frames are not randomly allocated "pieces" of linguistic knowledge. First, they are organized around a certain concept. "But, in contrast to a simple set of associations, these units contain the basic, typical and potentially possible information that is associated with a particular concept" (Van Dyke, 1989: 16).

For example, "The English verb to say, described in the diffuse definition system, looks like a collection of a number of separate, unrelated values, internally united by several common characteristics for them. The characteristics inherent only in this verb (as common to all its meanings, and present only in some of them) are integral (see description in any explanatory dictionary of the English language), looks like a fragment of some system of four units; using the signs 1 for the presence of a characteristic and 0 for its absence, Yu.K. Lekomtsev encodes the fragment as follows: the first sign ( 1 or 0 ) refers to the use of the verb in direct speech, the second sign - in indirect speech, the third sign - in the presence of an object of a certain semantic character, the fourth sign - if there is a speaker of speech (see Table. 1). 
Table 1. English verb "to say"

\begin{tabular}{|c|l|c|c|c|}
\hline Item No. & \multicolumn{1}{|c|}{ verb } & $13^{\text {th }}$ century & $13^{\text {th }}-14^{\text {th }}$ century & $17^{\text {th }}-20^{\text {th }}$ century \\
\hline 1 & Сказать 1001 & mapelian & guethen & to say \\
\hline 2 & Говорить 0100 & cwepan & seyen & to tell \\
\hline 3 & Рассказывать 0110 & secgan & tellen & - \\
\hline 4 & Говорить (процесс речи) 0000 & sprecan & speken & to speak \\
\hline
\end{tabular}

The above example shows that the differential characteristics need not necessarily be purely semantic, but can be, as in this case, syntactic and semantic-syntactic. In developed systems, in contrast to this example, the description is usually conducted along two independent lines - along the line of semantic signs that form a lexical meaning, and along the line of combining the words that form the distribution" (Stepanov, 1977: 301). The exposition of the frame of verbs of speaking in English is presented in the form of some elementary model, combining in a single whole the facts of the history of the language with linguistic and cultural processes. Words are grouped together on the basis of a semantic attribute, according to which the verbs of speaking are classified. So, the verb sprecan has a special sign "speaking in an ethnically specific language", etc.

So, the study of the interrelationship of cultural themes and language involves addressing certain groups of words held for centuries along with the fact that they are motivated, defined and mutually structured by a special construction of knowledge behind the given area of the dictionary. In this sense, we can postulate the presence in the vocabulary of certain analogues of the concept of "frame" of cognitive linguistics, which have common grounds for images. However, the phenomenon that we postulate differs from the actual frame by the diachronic multilayer, resulting from a change in cultural notions.

The cultural frame can be embodied in the lexical net of the concept. The Old English lexeme synn "sin", according to the etymological dictionary (Holthausen, 1974: 340), is interpreted as follows: synn - sin, wine; crime, injustice; insult, feud; English sin, Old Frisian sende, Old Saxon sundae, Old High German suntea, Norse synd, refers to Old Saxon and Old High German sunnea - hindrance, need, Norse syn - negation, Latin sons - guilty.

The concept of sin in the Anglo-Saxon picture of the world, with the adoption of Christianity, is directly reflected in the lexemes of the language. Based on (A Concise AngloSaxon Dictionary), (An Anglo-Saxon dictionary, (Baker, 2007)), we give the main 35 nouns that denote the concept of SIN (Table 2).

So, with the process of adoption of Western Christianity, at least 35 nouns reflect the concept of $\sin$ in the Old English language. Let us present as an illustrative example of the lexeme morpdced murder, deadly sin, crime (Old English contexts are represented by: (An Anglo-Saxon dictionary, based on the manuscript collections of the late Joseph Bosworth)).

“Hé gewenede swá hine sylfne tó heora synlícum peáwum and tó márum morǽdǽdum mid ðam mánfullum flocce... Swá férde se cniht on his fracepum dǽdum and on morǽdǽdum micclum gestrangod on orwénnysse his ágenre hǽle, Ælfc. T.Grn. 17, 18-24” (He reconciled with them, with sinners, with their mortal sins and with that evil society. Then this young man was plunged into his misdeeds and mortal sin, but he triumphed over despair and his fortune).

“Wearp ðes peódscype swýðe forsyngod. . . Purh morǽdǽda and purh mándǽda, Wulfst. 163, 21” (The 
Table 2. The concept SIN in the Anglo-Saxon worldview

\begin{tabular}{|c|c|c|}
\hline 1 & ægylt & $\begin{array}{l}\text { sin, offence, a breach or violation of the law, a } \\
\text { trespass fault }\end{array}$ \\
\hline 2 & bealudæd & evil, deed sin \\
\hline 3 & culpa & fault, sin \\
\hline 4 & déapfiren & deadly sin \\
\hline 5 & deápscyld & crime worthy of death a death-fault capital crime \\
\hline 6 & eftforgiefnes & remission, forgiveness of $\sin$ \\
\hline 7 & eofot & crime, sin, guilt \\
\hline 8 & fácen- (facnes/-) & $\begin{array}{l}\text { deceit, fraud, treachery, sin, evil, crime, blemish, } \\
\text { fault }\end{array}$ \\
\hline 9 & fácendæd & sin, crime \\
\hline 10 & firen & $\begin{array}{l}\text { Transgression, sin, crime, outrage, violence, } \\
\text { torment, suffering }\end{array}$ \\
\hline 11 & firenleahter & great $\sin$ \\
\hline 12 & firensynn & great $\sin$ \\
\hline 13 & firenweorc & evil, deed sin \\
\hline 14 & frumscyld & original sin \\
\hline 15 & godscyld & sin against God impiety \\
\hline 16 & gylting & $\sin$ \\
\hline 17 & heáfodleahter & a capital offence, mortal sin \\
\hline 18 & heáhsynn & deadly sinn crime \\
\hline 19 & heáfodgylt & a capital crime deadly sin \\
\hline 20 & níðsynn & grievous sin \\
\hline 21 & morðor & $\begin{array}{l}\text { deed of violence, murder, homicide, } \\
\text { manslaughter, mortal sin, crime, injury, } \\
\text { punishment, torment, misery }\end{array}$ \\
\hline 22 & morpdæd & murder, deadly sin, crime \\
\hline 23 & synbend & bond of $\sin$ \\
\hline 24 & synbót & penance amends for sin \\
\hline 25 & synbryne & burning ardor of sin, sinful passion \\
\hline 26 & synbyrðen & burden of $\sin$ \\
\hline 27 & syndæd & a sinful deed sin, wicked act \\
\hline 28 & synleahter & stain of $\sin$, a sinful fault $\sin$ \\
\hline 29 & synléaw & injury caused by sin, sinful injury \\
\hline 30 & synn & sin, guilt, crime \\
\hline 31 & synnlust & desire to sin, sinful desire or pleasure lust \\
\hline 32 & synrúst & canker of sin, the foulness of $\sin$ \\
\hline 33 & synwracu & the punishment for $\sin$ \\
\hline 34 & synwund & wound of sin, a wound inflicted by sin \\
\hline 35 & wróht & $\begin{array}{l}\text { blame, reproach, accusation, slander, fault, crime, } \\
\text { sin, injustice, strife, enmity, anger, contention, } \\
\text { dispute, hurt, injury, calamity, misery }\end{array}$ \\
\hline
\end{tabular}


value of this penance is that the sinner ... with its help is cleansed of both mortal sin and crime).

Consequently, the concept sin directly varies from the depth of religious knowledge, from the adoption of Gospel wisdom, regardless of the social status of the sinner.

\section{Layers and layers in grammar. Grammatical concepts in language and culture}

Sometimes for the verification of cultural content in texts, a more detailed study of layers or strata in grammar is required. To describe each layer of grammar, you need tools and concepts that may not be necessary at all for another layer.

This difference in categorization, carried out by a researcher, is often quite definitely reinforced by the presence in the layer itself of any formal means that can be absent in another layer. Thus, the archaic layer of English widely uses the morpheme -(e)n both in the name and in the verb. And it is especially important that this formal tool does not just belong to the morphology of the name or only the morphology of the verb, namely it unites them in one layer of grammar, opposing to other layers. There are many such examples. So, F.F. Fortunatov showed that in the Old Slavonic language the inflexion of one person singular in its archaic form in the verb "I learned" is a "fragment" of the paradigm of the Indo-European perfection, i.e. $\measuredangle ъ \partial ъ$ comes from $v b d e n$, and that the verbal morpheme *-en is here materially the same as in the name of the type of съма, има (similarity to the English morpheme -en is of course not essential here) (Stepanov, 1981: 334).

Another material of the conceptualization in the text is the material of the Old Germanic languages, in particular, the Gothic, where the category of animate/inanimate characteristic of the Proto Indo-European is still preserved as a relic phenomenon in the paradigm of declension of Gothic nouns (Osipova, 1980). In this case, the interrelation of language and culture is crucial for the search of conceptual embodiments of the disappeared paradigms. The compact material of the Gothic language allows reconstructing grammatical relations, which were typical for the Proto Indo-European grammar. In the oldest IndoEuropean (general Indo-European) language, two gender systems are traced: 1) the distinction between the animate-inanimate gender and 2) the distinction between the masculine-feminineneuter genders. These systems do not lie in one plane and belong in origin to different historical epochs. The oldest of these is the animateinanimate gender, behind which, with a deep historical reconstruction, an even more ancient opposition of the active and inactive substances.

For example, words with the base *pedmeans "leg" and belong to the active class, words with the base *pedo- "footprint" belong to the inactive class. The existence of this multi-component system is indicated by various facts of historically attested Indo-European languages. Thus, in the Latin pater-mater, the "father" - "mother", or lupus-fagus, "wolf" "beech tree", does not contain any indicators of gender differences between "masculine" and "feminine" in the structure of their word forms, because before that they all belonged to the same "animated" gender. In Latin, they differ only by agreeing with the same adjectives: with the words pater, lupus, adjectives of the masculine gender are consistent, and with the words mater, fagus adjectives of the feminine gender, i.e. a formal difference is achieved by clearly later means. Among the words belonging to the old layer of "animate", there are no such semantic differences that would correspond to the later division into the "masculine gender" and "feminine gender", except for the few cases in all, when these words denote a female or a male. Thus, the form of the 


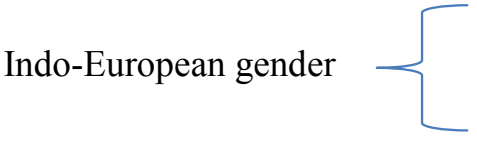

\section{animate \\ inanimate}

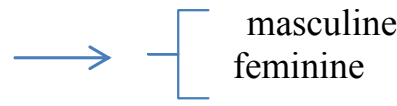

neuter

Fig. 1

words lupus and fagus and their meaning - for those who do not know the whole Latin system does not allow us to conclude which of them will be the word of the masculine, and which is the word of the feminine gender. This can be summarized as follows (Fig. 1).

In other words, while the animate gender was transformed in the later system into a twomembered masculine and feminine genders, the old inanimate gender acquired a new meaning (relative to the other two masculine and feminine genders), i.e. the value of the neuter genders. Knowing the common organization of the category of the gender in the Indo-European, many phenomena can be explained in the ancient Indo-European languages: Old Slavonic, Greek, Latin and new languages, for example, in Russian. Thus, the names of small animals whose sex differences are insignificant in the life of a person belong mainly to the feminine gender, by virtue of the general tendency of the feminine gender to designate not a common, but a kind of common. The names of celestial bodies, fire, day and night are remnants of the old animate kind; therefore in historical ancient Indo-European languages they are always both the masculine and feminine genders. Variations of the masculine and feminine genders in these cases turn out to be secondary particularities, conditioned by a specific system or even by a fragment of each individual language. Thus, in Latin, the word dies "day" was originally a masculine word, but then passed into the feminine gender under the influence of other words in -ies, and also influenced by the semantics of the correlative word nox "night" of the feminine gender. Obviously, from the point of view of the inherited nominal classification, this is already a particularity; the decisive importance is the belonging of this word to the "non-neuter" kind. The names of the action (and this takes place very consistently), for example, in the ancient Greek language is always masculine and feminine, while the names of the results of the action are always of the neuter gender; cf. Greek. $\pi \lambda \eta \dot{\rho} \omega \sigma \iota \varsigma$; feminine "filling" and neuter. $\pi \lambda \eta ́ \rho \omega \mu \alpha$ ("filling, completeness") and means of different grammatical forms of their names was not the absolute beginning of the category of animate gender, but continued deep traditions of Indo-European thinking (Stepanov, 1975: 128).

The category of animate gender and its reflection in the paradigm of the declension of the ancient German nouns is interesting for us in the fact that in the system of the ancient Germanic declension there are relict phenomena, indicative of the more ancient, clearly expressed in the opposition language, animate (active) inanimate (inactive), preceding the system of declension in the masculine, feminine and neuter genders. Thus, this process can be seen in the declension of masculine nouns with a basis for -an: "The noun model with the -an suffix reflected the Indo-European nomina agentis model, but it was in the Germanic languages that it became widespread. The main content of the model of nouns with the basic suffix -on- make up the animate nouns of the feminine gender. Models of nouns with the suffix -jan- were represented in all Germanic languages very widely. These were models of a masculine actor. Some of the feminine nouns -jon- bases were also represented by mutated 
animated nouns of the feminine gender. As for the declension of the substantive nouns $-i$ and $-\mathrm{u}$, it is known that in the proto-Indo-European (or early Indo-European) it was possible to oppose - $i$ the foundations of the neuter gender and $-i$ the basis of the animate kind; the same for -i- bases, which are partially preserved in the ancient Germanic languages. Finally, it is generally accepted that r-bases (i.e. suffixes -r-, -er-, -ter-/-tor-) in the Indo-European languages were related to the names of the kinship and the names of the actors. The names of kinship of masculine and feminine gender, having in the early Germanic a single paradigm, are related only to Old Germanic r-basics" (Osipova, 1980: 5-6). There is the form of the following hypothetical reconstruction for Old Germanic: words with consonant basics belonged in the past mainly to animate genders, words with basics on the vowel are built into the earlier system of declension of an inanimate kind or passive.
Let us summarize. Linguosemiotic types are conceptual systems and they appear within the framework of historical and cultural conceptualizations. What are the reasons for this variety of formal means of expression of conceptual and cultural systems of Indo-European languages and cultures? It is very likely that the answer to this question may be subject domains in the semiotics of culture, in particular, the linguistic codes of the Indo-European culture. In the semiotic sense, this type of information appears as some more general knowledge of language and culture, as knowledge of the semiotics of culture. Thus, this general knowledge is sifted through the sieve of the semiotic tradition, it is not amorphous, because itself it is organized into the conceptual systems, discussed above, representing the key moments of the connection between language and culture. In accordance with this view, each ethnic language, first of all, a member of the language family, is connected by regularhistorical relations of sounds (and minimal significant elements).

\section{References}

Abaev, V.I. (1970). Otrazhenie raboty soznanija v leksiko-semanticheskoj sisteme jazyka. Leninizm i teoreticheskie problemy jazykoznanija [Reflexion of consciousness's work in lexicalsemantic system of language]. Moscow.

A Concise Anglo-Saxon Dictionary (1916). John R.Clark Hall. Available at: http://www.ling. upenn.edu/ kurisuto/germanic/oe_clarkhall_about.html (Accessed: 4.01.2018).

An Anglo-Saxon dictionary, based on the manuscript collections of the late Joseph Bosworth. Available at: http://lexicon.ff.cuni.cz/texts/oe_bosworthtoller.html (Accessed: 4.01.2018).

Arapova, N.S. (1990). Jevfemizm [Euphemism]. In Lingvisticheskij jenciklopedicheskij slovar'. Moscow.

Baker Peter, S. (2007). Introduction to Old English. Malden, MA: Blackwell Pub.

Baskova, Ju.S. (2009). Manipuljacija v jazyke SMI: jevfemizmy kak «slova-prikrytija» [Manipulation in the language of mass media: euphemisms as cover words]. Krasnodar: KSJeI.

Benvenist, Je. (2002). Obshhaja lingvistika [General linguistics]; per. s fr., obshh. red., vstup. st. i komment. Ju.S. Stepanova, 2-e izd., stereotip. Moscow: Editorial URSS.

Debray, R. (2010). Vvedenie v mediologiju [Introduction into mediology]. Per. s fr. B.M. Skuratova. Moscow: Praksis.

Holthausen, F. (1974). Altenglisches etymologisches Wörterbuch. Heidelberg.

Karpova, E.A. (2002). Interpretacija drevneanglijskogo pojeticheskogo teksta: opyt lingvokul'turologicheskogo analiza naimenovanij stran sveta v pojeme «Beovul'f» [Interpretation of 
Old English poetry: experience of linguocultural analysis of world coordinates in the poem "Beowulf”]. In Rannesrednevekovyj tekst: problemy interpretacii, otv. red. N.Ju. Gvozdeckaja and I.V. Krivushin. Ivanovo. P. 190-202.

Kolesov, V.V. (1986). Mir cheloveka v slove Drevnej Rusi [The man's world in the narrative of Old Russia]. Learning.

Osipova, O.A. (1980). Otrazhenie kategorii odushevlennosti/neodushevlennosti v paradigme sklonenija $v$ drevnegermanskih jazykah [Reflexion of the category animate inanimate in the paradigm of declension of Old Germanic language]. Tomsk.

Polomé, E.C. (1982). Indo-European culture with special attention to religion. In Indo-Europeans in the fourth and third millennia. Austin.

Polomé, E.C. (1985). Der indogermanischen Wortschatz auf dem Gebiete der Religion. In Indogermanische Gesellschaft. Symposium, Innsbruck.

Polomé, E.C. (1989). Preparing an etymological dictionary of Protogermanic: methodological problems. In Material of the conference "Paradigmatic and syntagmatic investigations in Germanic languages". Vilnius, May 11-13.

Puhvel, J. (1984). Hittite etymological dictionary. Berlin; New-York; Amsterdam. Vol. 1.

Reformatskij, A.A. (1996). Vvedenie v jazykoznanie [Introduction into the studies of language]. Moscow: Aspekt Press.

Steblin-Kamenskij, M.I. (1978). Mif [Myth]. Learning.

Stepanov, Ju.S. (1971). Semiotika [Semiotics]. Moscow.

Stepanov, Ju.S. (1975). Osnovy obshhego jazykoznanija [The basis of language studies]. Moscow.

Stepanov, Ju.S. (1977). Nominacija, semantika, semiologija (Vidy semanticheskih opredelenij $\mathrm{v}$ sovremennoj leksikologii) [Nomination, semantics, semiology (types of semantic definitions in modern lexicology)]. In Jazykovaja nominacija. Obshhie voprosy. Moscow.

Stepanov, Ju.S. (1981). Imena, predikaty, predlozhenija [Names, predicates, sentences]. Moscow.

Stepanov, Ju. S. (2003). Smysl, absurd i jevfemizmy [Senses, absurdity, euphemisms]. In Vestn. NGU.Ser.: Lingvistika i mezhkul'turnaja kommunikacija. Novosibirsk. T. 1. Vyp. 1. P. 7-10.

The Anglo-Saxon Chronicle: An Electronic Edition. (Vol. 5) literary edition. Available at: httpasc. jebbo.co.ukbb-L.html (Accessed: 4.01.2018).

Trier, J. (1942). Zaun und Mannring. In Beiträge zur Geschichte der deutschen Sprache und Literatur.

Trubachev, O.N. (1987). Slavisticheskij kommentarij k rekonstrukcii indoevropejskoj kul'turnoj drevnosti [Slave commentary to the reconstruction of Indo-European cultural entities]. In Materialy Vsesojuznoj konferencii "Teorija lingvisticheskoj rekonstrukcii” AN SSSR. Moscow.

Van-Dejk, T.A. (1989). Jazyk. Poznanie. Kommunikacija [Language. Gnoseology. Communication]. Per. s angl., Sost. V.V. Petrov. Moscow. 


\title{
Лингвосемиотические типы концептуализаций
}

в языке и культуре

\author{
С.Г.Проскурин, А.В.Проскурина \\ Новосибирский государственный технический \\ университет \\ Россия, 630073, Новосибирск, пр. К. Маркса, 20
}

В настоящей работе рассматриваются некоторые лингвосемиотические типы концептуализаций в языке и культуре. Вопросы относятся к идентификации концептуальных моделей в семиотике индоевропейской культуры. Под лингвосемиотическими типами понимаются концептуальные системы, которые включают всю синхронную область смыслов, в том числе предысторию (т.е. эволюиию). Таким образом, в работе производится ориентация на концептуальные системы индоевропейского языка и культуры, в том числе и на исследовательские системы, изучающие взаимодействие языка и культуры на материале дописьменных и письменных традиций, а также на концептуальные структуры (концепты, мифологические архетипы и т.д.), которые имеют гипотетическое и историческое прочтение. Предметом исследования стали ключевые культурные концепты и их роль в реконструкции индоевропейской культуры, концептуальные культурные фреймы, а также концептуальные слои и пласть в грамматике или грамматические конщепты в языке и культуре.

Ключевые слова: индоевропейская семиотика, концептуализации, концептуальные модели, культурные фреймы, грамматические концепты.

Исследование выполнено за счет гранта Российского научного фонда (проект № 14-28-00130) в Институте языкознания РАН.

Научная специиальность: 10.00.00 - филологические науки, 24.00.00 - культурология. 